\title{
Erythrocytes, erythrocyte membranes, neutrophils and platelets as biopsy materials for the assessment of zinc status in humans
}

\author{
BY MANUEL RUZ*, KELLEY R. CAVAN, WILLIAM J. BETTGER \\ AND ROSALIND S. GIBSON† \\ Division of Applied Human Nutrition and Department of Nutritional Sciences, University of Guelph, \\ Guelph, Ontario, Canada NIG $2 W 1$
}

(Received 2 April 1991-Accepted 23 August 1991)

\begin{abstract}
During a controlled zinc depletion-repletion study, fifteen men aged 25.3 (SD 3.3) years were fed on a low-Zn diet with high phytate: $\mathrm{Zn}$ and phytate $\times$ calcium : $\mathrm{Zn}$ molar ratios for 7 weeks, followed by a 2 week repletion period when $30 \mathrm{mg}$ supplemental $\mathrm{Zn} / \mathrm{d}$ was given. Changes in plasma, urine, and hair $\mathrm{Zn}$ concentrations, taste acuity, and cellular immune response confirmed the development of mild $\mathrm{Zn}$ deficiency. $\mathrm{Zn}$ concentrations in neutrophils, platelets, erythrocytes and erythrocyte membranes, mean platelet volume, and activities of alkaline phosphatse $(E C$ 3.1.3.1) and $x$-D-mannosidase $(E C$ 3 2.2 .1 .24$)$ in neutrophils did not respond to changes in $\mathrm{Zn}$ status. In contrast, alkaline phosphatase activity in erythrocyte membranes showed a significant decline which was consistent in all subjects (nmol product formed/min per mg protein; baseline v. 7-week Zn depletion, 0.656 (SD 0.279) v. 0.506 (SD 0.230), at 7 weeks; $P<0.05$ ); neutral phosphatase activity remained unchanged. Alkaline phosphatase activity in erythrocyte membranes may be a potential index of $\mathrm{Zn}$ status in humans.
\end{abstract}

Experimental zinc deficiency: Humans: Phytate: Neutrophils: Platelets

The importance of zinc for human nutrition has been recognized for about 25 years. During this time many important advances in the understanding of the role of $\mathrm{Zn}$ in human metabolism have been made. Nevertheless, the diagnosis of mild $\mathrm{Zn}$ deficiency in the population is still an unsolved problem (Solomons, 1979; Prasad, 1985a,b).

In adult humans less than $0.5 \%$ of the total body $\mathrm{Zn}$ content is in the blood, of which $12-22 \%$ is in plasma, approximately $3 \%$ in leukocytes and platelets, and $75-88 \%$ is in erythrocytes. The most widely used biopsy material for the assessment of $\mathrm{Zn}$ status is blood, of which plasma or serum is the most popular component (Solomons, 1979; Prasad, 1985 b). Some (Meadows et al. 1981; Prasad \& Cossack, 1982), but not all (Milne et al. $1985 a, b$ ), investigators have suggested that concentrations of $\mathrm{Zn}$ in mixed leukocytes or specific sub-populations of leukocytes (i.e. neutrophils and lymphocytes) are more reliable indices of $\mathrm{Zn}$ status than plasma $\mathrm{Zn}$ detecting 'short-term' changes in $\mathrm{Zn}$ status, because of their relatively short life-span (Prasad \& Cossack, 1982; Prasad, 1985b). In contrast, erythrocytes have a slow turnover and hence their $\mathrm{Zn}$ concentration does not reflect recent $\mathrm{Zn}$ status; whether the $\mathrm{Zn}$ concentration of total erythrocytes, or of the erythrocyte membrane, or both, reflect 'long-term' Zn status remains unclear (Prasad et al. 1978; Rabbani et al. 1987). The activities of selected $\mathrm{Zn}$ metallo-enzymes in neutrophils and

* Present address: Department of Nutrition, Faculty of Medicine, University of Chile. Independencia 1027 , Santiago, Chile.

+ For reprints. 
erythrocytes from subjects with some degree of $\mathrm{Zn}$ deficiency have also been investigated; results have also been equivocal (Ballester \& Prasad, 1983; Prasad, 1985a; Milne et al. 1987).

Previously we reported changes in plasma, urine, and hair Zn concentrations, taste acuity and cellular immune response during an experimentally controlled $\mathrm{Zn}$ depletion-repletion study, which confirmed the development of mild $\mathrm{Zn}$ deficiency in fifteen young adult men (Ruz et al. 1991). In the present study we have evaluated the responses of selected variables in erythrocytes, neutrophils, and platelets as potential indices of $\mathrm{Zn}$ status during the experimentally induced mild $\mathrm{Zn}$ deficiency state, and during subsequent $\mathrm{Zn}$ repletion. The variables assessed were: $\mathrm{Zn}$ concentrations in erythrocytes, erythrocyte membranes, neutrophils, platelets, platelet count, mean platelet volume (MPV), and the activities of alkaline (EC 3.1.3.1) and neutral phosphatases in erythrocyte membranes, and $\alpha$-Dmannosidase (EC 3.2.1.24) and alkaline phosphatase in neutrophils. This is the first time that $\alpha$-D-mannosidase activity in neutrophils and changes in Zn-related erythrocyte membrane variables have been monitored during an experimentally controlled $\mathrm{Zn}$ depletion-repletion study in humans. The responses of the static indices (i.e. concentrations of $\mathrm{Zn}$ in neutrophils, platelets, and erythrocytes) were evaluated each week to provide information on weekly variations.

\section{SUBJECTS AND METHODS \\ Experimental design}

The study was approved by the Human Ethics Committee of the University of Guelph. A detailed description of the subjects, experimental design, and dietary manipulations of the Zn depletion-repletion study has been published earlier (Ruz et al. 1991). Briefly, fifteen young adult males (mean age $25 \cdot 3$ (SD 3.3) years) attending the University of Guelph participated in the 16-week study. The study had four phases: equilibration, $\mathrm{Zn}$ depletion, $\mathrm{Zn}$ repletion, and follow-up. The first week of the study (equilibration) comprised an adaptation period to the soya-bean-protein- and egg-albumin-based diets to be used throughout most of the depletion phase of the study. The following 7 weeks comprised the $\mathrm{Zn}$-depletion phase. In the first week of this period subjects received a semi-purified liquid diet based on egg albumin containing $0.6 \mathrm{mg} \mathrm{Zn} / \mathrm{d}$, added phytic acid $(1.27 \mathrm{~g} / \mathrm{d})$, and a calcium supplement (Caltrate; Lederle, Montreal, Quebec). As a result the average phytate: $\mathrm{Zn}$ and phytate $\times \mathrm{Ca}: \mathrm{Zn}$ molar ratios of the semi-purified liquid diets were 209 and 4116 respectively. During the rest of the 6 weeks of the depletion phase subjects received the egg-albumin- and soya-bean-protein-based diets used in the equilibration phase, modified to contain approximately $4 \mathrm{mg} \mathrm{Zn} / \mathrm{d}$, and average phytate: $\mathrm{Zn}$ and phytate $\times \mathrm{Ca}: \mathrm{Zn}$ molar ratios of 58 and 1853 respectively. For the 2 -week $\mathrm{Zn}$ repletion phase subjects received these non-meat diets, but with the daily addition of a $\mathrm{Zn}$ supplement (30 $\mathrm{mg} \mathrm{Zn/d}$ in the form of zinc gluconate). Total $\mathrm{Zn}$ intake during the 2-week repletion period was $35 \mathrm{mg} / \mathrm{d}$. Vitamin and mineral supplements were also given to the subjects throughout the study period to ensure that their nutrient intakes (with the exception of $\mathrm{Zn}$ ) met the recommended intakes for Canadians (Health and Welfare, 1990).

Throughout the first 10 weeks of the study all foods and beverages were supplied by the researchers, who maintained strict control of all items consumed. Subjects were informed that $\mathrm{Zn}$ concentrations in plasma and urine, and urinary creatinine would be assessed weekly to monitor compliance with the study protocol.

The final 6 weeks of the study comprised the follow-up phase in which the subjects consumed their usual self-selected diets plus an additional $\mathrm{Zn}$ supplement of $5 \mathrm{mg} \mathrm{Zn} / \mathrm{d}$ as zinc gluconate. 


\section{Measurements}

Fasting blood and $24 \mathrm{~h}$ urine samples were obtained at weekly intervals from week 1 to week 10 , with an additional sample at week 16 for thirteen of the fifteen subjects, and analysed for selected indices of $\mathrm{Zn}$ status. Scalp hair samples taken at the end of the baseline (week 1), depletion (week 8), and follow-up (week 16) were also analysed for $\mathrm{Zn}$. In addition, selected physiological functional tests of $\mathrm{Zn}$ status (i.e. cellular immune response and taste acuity) were evaluated. Results for some of these determinations have been presented in detail elsewhere (Ruz et al. 1991) and, where necessary, are summarized briefly here. The present paper focuses on the findings in platelets, neutrophils, erythrocytes and erythrocyte membranes.

Following an overnight fast, $30 \mathrm{ml}$ fasting blood was taken with subjects in the sitting position in trace element-free evacuated tubes (Vacutainer; Becton Dickinson, Rutherford, NJ, USA) containing, where appropriate, either $\mathrm{Zn}$-free and preservative-free heparin, EDTA, or ACD (25 g trisodium citrate/ $1,14 \mathrm{~g}$ citric acid $/ 1,20 \mathrm{~g}$ dextrose $/ 1$ ) as an anticoagulant. Blood samples taken using heparin were used for tests described previously (Ruz et al. 1991). Blood samples taken with EDTA were used for routine haematology analyses, which included MPV, and platelet, leukocyte and lymphocyte counts performed using an automated method (Coulter counter; Coulter Electronics Ltd, Nortwell Drive, Luton, Beds, UK). All reagents were analysed for $\mathrm{Zn}$ content before use by atomic absorption spectrophotometry (AAS); they all contained negligible amounts of $\mathrm{Zn}$.

Separation of platelets, neutrophils, erythrocytes and erythrocyte membranes

Platelets and neutrophils were isolated as follows: $7-10 \mathrm{ml}$ blood were collected in a tube containing $1.5 \mathrm{ml} \mathrm{ACD}$ and centrifuged for $20 \mathrm{~min}$ at $300 \mathrm{~g}$. Plasma was transferred carefully, to avoid contamination with erythrocytes, to a $15 \mathrm{ml}$ centrifuge tube and centrifuged for $15 \mathrm{~min}$ at $1530 \mathrm{~g}$. Platelet-poor-plasma (ppp; $2 \mathrm{ml}$ ) was saved for further use during the neutrophil separation. The pellet was visually inspected and, if erythrocytes were detected, $4 \mathrm{ml}$ cold distilled deionized water was added for $30 \mathrm{~s}$, followed by $4 \mathrm{ml}$ sodium chloride $(18 \mathrm{~g} / 1)$ and centrifugation for $15 \mathrm{~min}$ at $1530 \mathrm{~g}$. The pellet was suspended in $3 \mathrm{ml}$ PBS buffer, pH $7 \cdot 4$ (containing, $\mathrm{g} / \mathrm{l}: \mathrm{NaCl} 7 \cdot 1$, disodium hydrogen phosphate $1 \cdot 15$, potassium dihydrogen phosphate $0 \cdot 2$, potassium chloride $0 \cdot 2$ ). A $20 \mu 1$ portion was diluted in $25 \mathrm{ml}$ Isotone II (Coulter Electronics of Canada, Burlington, Ontario) and platelets counted using a Coulter counter. The remaining platelet suspension was kept at $-70^{\circ}$ until further analysis.

Packed erythrocytes and buffy coats were transferred to a $15 \mathrm{ml}$ tube and $1 \mathrm{ml}$ Dextran $\mathrm{T}-500$ reagent $(60 \mathrm{ml} / \mathrm{l})$ prepared in saline $(9 \mathrm{~g} \mathrm{NaCl} / 1)$ was added (Pharmacia, Dorval, Quebec), followed by enough saline to produce a total volume of $10 \mathrm{ml}$. The mixture was then gently mixed and allowed to stand undisturbed for $45 \mathrm{~min}$. The supernatant fraction was removed and centrifuged for $6 \mathrm{~min}$ at $280 \mathrm{~g}$. The pellet was retained and resuspended in $8 \mathrm{ml}$ ppp-saline reagent (prepared by mixing $2 \mathrm{ml}$ ppp and $8 \mathrm{ml}$ saline). This suspension was carefully loaded into a tube containing $3 \mathrm{ml}$ Ficoll-paque (Pharmacia, Dorval, Quebec) and centrifuged for $25 \mathrm{~min}$ at $750 \mathrm{~g}$. The pellet was retained. Cold distilled deionized water $(4 \mathrm{ml})$ was added to lyse the remaining erythrocytes and, after no more than $30 \mathrm{~s}, 4 \mathrm{ml} \mathrm{NaCl}$ $(18 \mathrm{~g} / \mathrm{l})$ was added to restore isotonicity. The mixture was centrifuged for $6 \mathrm{~min}$ at $280 \mathrm{~g}$ and the supernatant fraction was discarded. If, after visual inspection, erythrocytes still remained, the lysis procedure was repeated. The pellet was suspended in $2 \mathrm{ml}$ PBS buffer, $\mathrm{pH} 7.4$ and centrifuged for $6 \mathrm{~min}$ at $280 \mathrm{~g}$. The supernatant fraction was discarded and the pellet re-suspended in $2 \mathrm{ml}$ PBS buffer and centrifuged for $6 \mathrm{~min}$ at $280 \mathrm{~g}$. The pellet was again suspended in $2 \mathrm{ml}$ PBS buffer. A portion $(50 \mu \mathrm{l})$ of the suspension was diluted in 
$25 \mathrm{ml}$ Isotone II solution and the neutrophil counts were performed using a Coulter counter; the remaining neutrophil suspension was kept at $-70^{\circ}$ until further analysis.

Erythrocytes were obtained by centrifugation of whole blood for $15 \mathrm{~min}$ at $300 \mathrm{~g}$. Plasma was separated. The packed erythrocytes were washed with isotonic phosphate buffer, $\mathrm{pH} 8.0$ (145 mM-NaCl-5 mM- $\mathrm{Na}_{2} \mathrm{HPO}_{4}$ ), and centrifuged for $15 \mathrm{~min}$ at $300 \mathrm{~g}$; this procedure was carried out three times.

Erythrocyte membranes were prepared according to the method of Steck et al. (1970), and frozen at $-70^{\circ}$ until analysed. For analysis, erythrocyte membranes were allowed to thaw and were sonicated for $15 \mathrm{~s}$ in a sonic dismembrator (Model 300; Fisher Scientific Co, Ottawa, Ontario). A $10 \mu$ l portion was used for protein determination according to the method of Markwell et al. (1978).

\section{Determination of $Z n$ concentrations in the isolated blood components}

Before analyses, a wet ashing procedure using concentrated nitric acid (Ultrex, JT Baker Chemicals Co, Phillipsburg, NJ, USA) (Clegg et al. 1988) was employed to ash portions of platelets, neutrophils, erythrocytes, and erythrocyte membranes. Ash was then dissolved in nitric acid (30 ml/l) and $\mathrm{Zn}$ determined by flame AAS (Varian model SpectrAA-30; Varian Techtron Ltd, Georgetown, Ontario) using a micro-sampler. Accuracy and precision of the method were assessed by ashing and analysing five samples of bovine liver (National Institute of Standards and Technology, Reference Material no. 1577), certified for $\mathrm{Zn}$. The mean for five determinations was 122.6 (SD 5.0) $\mu \mathrm{g} / \mathrm{g}$, compared with the certified value of 130 (SD 13) $\mu \mathrm{g} / \mathrm{g}$. Zn concentrations in platelets and neutrophils were expressed as nmol $/ 10^{10}$ cells, and $\mu \mathrm{mol} / 10^{10}$ cells respectively, as $\mu \mathrm{mol} \mathrm{Zn} / \mathrm{g}$ haemoglobin for erythrocytes (Nishi, 1980 ), and as $\mu \mathrm{mol} \mathrm{Zn} / \mathrm{g}$ protein for erythrocyte membranes.

\section{Determination of enzyme activities in neutrophils}

Neutrophils were analysed for the activities of alkaline phosphatase and acidic $\alpha$-Dmannosidase. The neutrophil suspension was thawed and sonicated two to four times for $15 \mathrm{~s}$ in a Fisher sonic dismembrator Model 300. Enzyme activities were determined immediately because of reported loss of activity during the pre-incubation period (De Chatelet \& Cooper, 1970).

The activity of neutrophil alkaline phosphatase was measured by a modification of the method by De Chatelet \& Cooper (1970). Briefly, $50 \mu \mathrm{l}$ sonicate was incubated for $60 \mathrm{~min}$ in a reaction mixture containing buffer $(0 \cdot 1 \mathrm{M}$-2-amino-2-methyl-1-propanol, $\mathrm{pH} 10.5)$ $500 \mu \mathrm{l} p$-nitrophenylphosphate $(4 \mathrm{mg} / \mathrm{ml}), 125 \mu \mathrm{l}$, distilled deionized water $125 \mu \mathrm{l}$; magnesium (from magnesium chloride) was present at a final concentration of $4 \mathrm{~mm}$. Reaction was stopped by the addition of $500 \mu \mathrm{l} 0.5 \mathrm{M}$-sodium hydroxide. Tubes were centrifuged for $15 \mathrm{~min}$ at $300 \mathrm{~g}$. The supernatant fraction was carefully removed and absorbance read at $405 \mathrm{~nm}$ against a reactive blank in a spectrophotometer.

The activity of neutrophil acidic $\alpha$-D-mannosidase was measured by an adaptation of the method of Faber \& Glew (1983). A portion $(50 \mu 1)$ of neutrophil sonicate was incubated for $90 \mathrm{~min}$ in a reaction mixture containing: $0.5 \mathrm{M}$-acetate buffer ( $\mathrm{pH} \mathrm{4.5)} 500 \mu \mathrm{l}, 10 \mathrm{~mm}-4$ nitrophenyl- $\alpha$-D-mannopyranoside $200 \mu \mathrm{l}$, distilled deionized water $150 \mu \mathrm{l}$. The reaction was stopped by adding $500 \mu 10.133 \mathrm{M}$-glycine- $\mathrm{NaOH}$ buffer, $\mathrm{pH} 11$. Tubes were centrifuged for $15 \mathrm{~min}$ at $300 \mathrm{~g}$. The supernatant fraction was removed and absorbance read against a reactive blank at $405 \mathrm{~nm}$ in a spectrophotometer (model DU-50; Beckman Instruments Inc, Jamboree, Irvine, CA, USA). Precision of the methods was assessed by analysing six samples of a pool of neutrophils divided into individual portions. The means for six 
determinations were 402.9 (SD 20.5) nmol product formed/h per mg protein for alkaline phosphatase, and 184.8 (SD 8.8) $\mathrm{nmol} / \mathrm{h}$ per $\mathrm{mg}$ protein for acidic $\alpha$-D-mannosidase. Protein was determined by the method of Markwell et al. (1978).

\section{Determination of enzyme activities in erythrocyte membranes}

Total alkaline phosphatase activity in erythrocyte membranes (AP-EM) was determined as follows: $100 \mu \mathrm{l}$ membrane suspension was incubated for $90 \mathrm{~min}$ at $37^{\circ}$ in a reaction mixture containing: $0 \cdot 1 \mathrm{M}$-2-amino-2-methyl-1-propanol buffer (pH 10.5) $500 \mu \mathrm{l}$, p-nitrophenylphosphate ( $4 \mathrm{mg} / \mathrm{ml}$; Sigma Chemical Co., St Louis, MO 63178, USA) $125 \mu \mathrm{l}$, distilled deionized water $75 \mu \mathrm{l}$; magnesium (from $\mathrm{MgCl}_{2}$ ) was present at a final concentration in the cuvette of $4 \mathrm{~mm}$. Reaction was stopped by the addition of $500 \mu \mathrm{l} 0.5 \mathrm{M}-\mathrm{NaOH}$. Tubes were centrifuged for $15 \mathrm{~min}$ at $300 \mathrm{~g}$ to remove the turbidity that develops after the addition of $\mathrm{NaOH}$. The supernatant fraction was carefully removed and absorbance due to the formation of $p$-nitrophenol was read at $405 \mathrm{~nm}$ against a reactive blank in a spectrophotometer (Beckman model DU-50). The blank contained the same components described previously except in this case the $\mathrm{NaOH}$ solution was added before the sample. Neutral phosphatase activity in erythrocyte membranes was determined using a $50 \mu \mathrm{l}$ sample incubated for $90 \mathrm{~min}$ at $37^{\circ}$ in a mixture containing: 2-hydroxymethyl-1,3propanediol (Tris) buffer ( $\mathrm{pH} \mathrm{7.4)} 500 \mu \mathrm{l}$, p-nitrophenylphosphate $(4 \mathrm{mg} / \mathrm{ml}$ ) $125 \mu \mathrm{l}$, distilled deionized water $125 \mu \mathrm{l}$; $\mathrm{Mg}$ was also present at $4 \mathrm{~mm}$. The rest of the procedure was performed in a manner similar to that described for alkaline phosphatase activity. Precision of the methods was evaluated by analysing a pooled sample (saved frozen in several portions on six occasions. Means ( $\mathrm{nmol}$ product formed $/ \mathrm{min}$ per $\mathrm{mg}$ protein) for the six determinations were 0.523 (SD 0.018 ) for alkaline phosphatase activity (coefficient of variation $(\mathrm{CV}) 3.4 \%$ ) and $1.605(\mathrm{SD} 0.088)$ for neutral phosphatase activity (CV $5.5 \%$ ).

\section{Statistical analysis}

All variables were tested for normality by the Kolmogorov-Smirnov test before any statistical comparisons were computed. Analysis of variance of repeated measures was performed to assess the significance of observed changes during the study. Contrasts were used to identify specific differences over time. Pearson's product-moment correlation coefficients were computed to assess relationships among selected variables (Snedecor \& Cochran, 1980). $P \leqslant 0.05$ was considered to be significant. All statistical analyses were carried out using the Statistical Package for the Social Sciences, SPSSx (SPSS Inc., 1986). All results are expressed as means and standard deviations.

\section{RESULTS}

The compliance during the study was very satisfactory; fourteen of the fifteen subjects completed the 7-week $\mathrm{Zn}$-depletion phase. The remaining individual received the low- $\mathrm{Zn}$ diets for 6 weeks, at which point measurements were considered to be 'at the end of $\mathrm{Zn}$ depletion'. This same individual successfully completed the 2 weeks of $\mathrm{Zn}$ repletion. Thirteen subjects volunteered to continue in the study during the 6 weeks of the follow-up phase.

Significant $(P<0.05)$ changes were observed in mean plasma $(\mu \mathrm{mol} / 1)$ and urinary $\mathrm{Zn}$ $(\mu \mathrm{mol} / \mathrm{d}$ ) : baseline 97.0 (SD 10.9) and 8.0 (SD 2.7), depletion 80.1 (SD 13.4) and 4.3 (SD 2.3), repletion 100.8 (SD 13.6) and $8 \cdot 2$ (SD 3.1) respectively, and in taste acuity $(0 \cdot 05<P<0 \cdot 10)$ and cellular immune responses $(P<0.05)$, emphasizing that marginal $\mathrm{Zn}$ deficiency had 
Table 1. Neutrophil zinc concentration ( $\mu$ mol/ $10^{10}$ cells) and activities (nmol product/h per $m g$ protein) at $37^{\circ}$ of $\alpha$-D-mannosidase (EC 3.2.1.24) and alkaline phosphatase (EC 3.1.3.1) in neutrophils during experimental $\mathrm{Zn}$ depletion and repletion in young adult male subjects*

(Mean values with their standard deviations)

\begin{tabular}{|c|c|c|c|c|c|c|c|}
\hline \multirow{2}{*}{$\begin{array}{l}\text { Experimental } \\
\text { period }\end{array}$} & \multirow{2}{*}{$\begin{array}{l}\text { Week } \\
\text { of study }\end{array}$} & \multicolumn{2}{|c|}{ Neutrophil Zn } & \multicolumn{2}{|c|}{$\alpha$-D-mannosidase } & \multicolumn{2}{|c|}{ Alkaline phosphatase } \\
\hline & & Mean & SD & Mean & SD & Mean & SD \\
\hline & & $1 \cdot 46$ & 0.53 & $212 \cdot 6$ & $65 \cdot 7$ & $413 \cdot 0$ & $184 \cdot 0$ \\
\hline \multirow[t]{7}{*}{ Depletion } & 1 & 1.43 & 0.29 & & & & \\
\hline & 2 & $1 \cdot 26$ & $0 \cdot 38$ & & & & \\
\hline & 3 & 1.32 & 0.46 & & & & \\
\hline & 4 & 1.46 & 0.43 & 178.9 & $91 \cdot 1$ & $376 \cdot 1$ & $210 \cdot 1$ \\
\hline & 5 & $1 \cdot 30$ & $0 \cdot 38$ & & & & \\
\hline & 6 & 1.41 & 0.52 & & & & \\
\hline & 7 & $1 \cdot 15$ & 0.44 & 217.9 & $79 \cdot 9$ & 535.8 & $276 \cdot 2$ \\
\hline \multicolumn{8}{|l|}{ Repletion } \\
\hline & 1 & $1 \cdot 22$ & 0.54 & & & & \\
\hline & 2 & 1.37 & 0.72 & $215 \cdot 1$ & $72 \cdot 7$ & $503 \cdot 2$ & $230 \cdot 0$ \\
\hline Follow-up & & $1 \cdot 31$ & 0.76 & $169 \cdot 2$ & $83 \cdot 9$ & $452 \cdot 3$ & $243 \cdot 6$ \\
\hline
\end{tabular}

* For details of procedures, see pp. 516-519.

been successfully induced by the dietary regimen of the present study. However, the activities of alkaline phosphatase, angiotensin-1-converting enzyme (EC 3.4.15.1) and acidic $\alpha$-D-mannosidase in plasma did not change. The responses of these biochemical and physiological functional indices of $\mathrm{Zn}$ status have been presented in detail elsewhere (Ruz et al. 1991).

In contrast, the concentrations of $\mathrm{Zn}$ in neutrophils (Table 1) did not show any significant trends during the study. Similarly, no significant responses to the dietary manipulations were noted for the activities of $\alpha$-D-mannosidase and alkaline phosphatase in neutrophils (Table 1). The mean platelet $\mathrm{Zn}$, total circulating platelet count, and MPV were also unaffected by the dietary treatments in the present study (Table 2), as were both the total leukocyte and lymphocyte counts reported earlier (Ruz et al. 1991).

The high dispersion of values observed at the different weeks of the study for some of the variables, particularly those related to neutrophils, is noteworthy. A visual inspection of values can lead to inaccuracies in the evaluation of the biological variation of the results, and $\mathrm{CV}$ are a more objective method of comparison. CV (\%) were: MPV 13.1, platelet $\mathrm{Zn}$ concentration $25 \cdot 7$, neutrophil $\mathrm{Zn}$ concentration $37 \cdot 3$, neutrophil alkaline phosphatase activity $50 \cdot 0$, neutrophil $\alpha$-D-mannosidase activity $40 \cdot 4$.

With few exceptions, no significant associations were observed among the variables analysed at baseline. These exceptions were neutrophil $\alpha$-D-mannosidase activity $v$. MPV $(r 0.60, P<0.05)$, and neutrophil $\mathrm{Zn}$ concentration $v$. total leukocyte count $(r-0.78, P<$ 0.05 ). None of the variables studied in platlets and leukocytes was correlated with initial plasma $\mathrm{Zn}$ concentrations.

Table 3 presents the $\mathrm{Zn}$ concentrations in erythrocytes and erythrocyte membranes observed during the study. No significant changes were evident, although $\mathrm{Zn}$ concentrations in erythrocyte membranes tended to decrease as the experimental period progressed $(P=$ $0.06)$. The results for the weekly $\mathrm{Zn}$ concentrations in erythrocytes emphasize the 
Table 2. Platelet zinc concentration (nmol/ $10^{10}$ cells), mean platelet volume $(f)$ and platelet count $\left(\times 10^{9} / l\right)$ during experimental $\mathrm{Zn}$ depletion and repletion in young adult male subjects*

(Mean values with their standard deviations)

\begin{tabular}{|c|c|c|c|c|c|c|c|}
\hline \multirow{2}{*}{$\begin{array}{l}\text { Experimental } \\
\text { period }\end{array}$} & \multirow{2}{*}{$\begin{array}{l}\text { Week } \\
\text { of study }\end{array}$} & \multicolumn{2}{|c|}{ Platelet $\mathrm{Zn}$} & \multicolumn{2}{|c|}{ Mean platelet volume } & \multicolumn{2}{|c|}{ Platelet count } \\
\hline & & Mean & $\mathrm{SD}$ & Mean & SD & Mean & SD \\
\hline Baseline & & $50 \cdot 6$ & $10 \cdot 6$ & $9 \cdot 25$ & $1 \cdot 17$ & $209 \cdot 5$ & $53 \cdot 3$ \\
\hline & 1 & $51 \cdot 7$ & $14 \cdot 2$ & $9 \cdot 47$ & $1 \cdot 12$ & $199 \cdot 0$ & $48 \cdot 2$ \\
\hline & 2 & $52 \cdot 0$ & $13 \cdot 3$ & $9 \cdot 83$ & $1 \cdot 33$ & 194.4 & $39 \cdot 3$ \\
\hline & 3 & 52.9 & $19 \cdot 3$ & $9 \cdot 28$ & $1 \cdot 13$ & $206 \cdot 7$ & $48 \cdot 8$ \\
\hline & 4 & $50 \cdot 2$ & $8 \cdot 6$ & $9 \cdot 68$ & $1 \cdot 40$ & $203 \cdot 8$ & $43 \cdot 7$ \\
\hline & 5 & $51 \cdot 4$ & $14 \cdot 7$ & $9 \cdot 88$ & $1 \cdot 33$ & 213.9 & $58 \cdot 0$ \\
\hline & 6 & $52 \cdot 0$ & $16 \cdot 4$ & 9.89 & 1.23 & $205 \cdot 6$ & $44 \cdot 2$ \\
\hline & 7 & 55.8 & $17 \cdot 3$ & 9.95 & $1 \cdot 39$ & $219 \cdot 7$ & 47.9 \\
\hline \multicolumn{8}{|l|}{ Repletion } \\
\hline & 1 & $53 \cdot 7$ & $9 \cdot 0$ & $10 \cdot 34$ & 1.61 & $217 \cdot 3$ & $51 \cdot 8$ \\
\hline & 2 & $52 \cdot 8$ & $15 \cdot 8$ & 9.98 & $1 \cdot 17$ & $219 \cdot 1$ & $50 \cdot 9$ \\
\hline Follow-up & & $46 \cdot 4$ & $8 \cdot 0$ & $9 \cdot 51$ & $1 \cdot 17$ & $221 \cdot 6$ & $49 \cdot 4$ \\
\hline
\end{tabular}

* For details of procedures, see pp. 516-519.

Table 3. Concentration of zinc in erythrocytes (umol/g haemoglobin) and erythrocyte membranes ( $\mu \mathrm{mol} / \mathrm{g}$ protein) during experimental $\mathrm{Zn}$ depletion and repletion in young adult male subjects*

(Mean values with their standard deviations)

\begin{tabular}{|c|c|c|c|c|c|}
\hline \multirow{2}{*}{$\begin{array}{l}\text { Experimental } \\
\text { period }\end{array}$} & \multirow{2}{*}{$\begin{array}{l}\text { Week } \\
\text { of study }\end{array}$} & \multicolumn{2}{|c|}{ Erythrocytes } & \multicolumn{2}{|c|}{ Erythrocyte membranes } \\
\hline & & Mean & SD & Mean & SD \\
\hline Baseline & & 0.52 & 0.08 & 0.72 & $0 \cdot 21$ \\
\hline & 1 & 0.55 & 0.08 & & \\
\hline & 2 & 0.52 & 0.07 & & \\
\hline & 3 & 0.53 & 0.08 & & \\
\hline & 4 & 0.55 & $0 \cdot 10$ & 0.61 & $0 \cdot 23$ \\
\hline & 5 & 0.52 & 0.07 & & \\
\hline & 6 & 0.52 & 0.07 & & \\
\hline & 7 & $0 \cdot 52$ & 0.07 & 0.67 & $0 \cdot 23$ \\
\hline Repletion & & & & & \\
\hline & 1 & 0.52 & 0.07 & & \\
\hline & 2 & 0.53 & 0.07 & 0.64 & 0.21 \\
\hline Follow-up & & $0 \cdot 53$ & 0.09 & $0 \cdot 58$ & $0 \cdot 24$ \\
\hline
\end{tabular}

* For details of procedures, see pp. $516 \div 519$.

consistency of the values throughout the study, unlike those observed for neutrophils and platelets (Table 1).

In Table 4 the activities of the two enzymes assayed in erythrocyte membranes are presented. Total neutral phosphatase activity did not change significantly during the study. In contast total AP-EM significantly decreased during the Zn-depletion phase $(P<0.01)$, followed by a slight (non-significant) increase during the Zn-repletion period. No further changes during the follow-up phase were noted. Fig. 1 presents the total change (baseline 
Table 4. Total alkaline (EC 3.1.3.1) and neutral phosphatase activities (nmol product/min per mg protein) at $37^{\circ}$ in erythrocyte membranes during experimental $\mathrm{Zn}$ depletion and repletion in young adult male subjects*

(Mean values with their standard deviations)

\begin{tabular}{|c|c|c|c|c|c|}
\hline \multirow{2}{*}{$\begin{array}{l}\text { Experimental } \\
\text { period }\end{array}$} & \multirow{2}{*}{$\begin{array}{l}\text { Week } \\
\text { of study }\end{array}$} & \multicolumn{2}{|c|}{$\begin{array}{c}\text { Total alkaline } \\
\text { phosphatase activity }\end{array}$} & \multicolumn{2}{|c|}{$\begin{array}{c}\text { Total neutral } \\
\text { phosphatase activity }\end{array}$} \\
\hline & & Mean & SD & Mean & SD \\
\hline \multirow{3}{*}{$\begin{array}{l}\text { Baseline } \\
\text { Depletion }\end{array}$} & & $0.656^{a}$ & 0.279 & 1.83 & 0.21 \\
\hline & 4 & $0.580^{b}$ & 0.284 & 1.84 & $0 \cdot 24$ \\
\hline & 7 & $0.506^{\circ}$ & 0.230 & 1.83 & $0 \cdot 20$ \\
\hline \multirow[t]{2}{*}{ Repletion } & & & & & \\
\hline & 2 & $0.529^{1114}$ & 0.246 & 1.82 & $0 \cdot 23$ \\
\hline Follow-up & & $0.523^{\mathrm{bc}}$ & 0.215 & $1 \cdot 84$ & $0 \cdot 23$ \\
\hline
\end{tabular}

a,b.c Mean with unlike superscript letters were significantly different: $P<0 \cdot 05$.

* For details of procedures, see pp. 516.519.

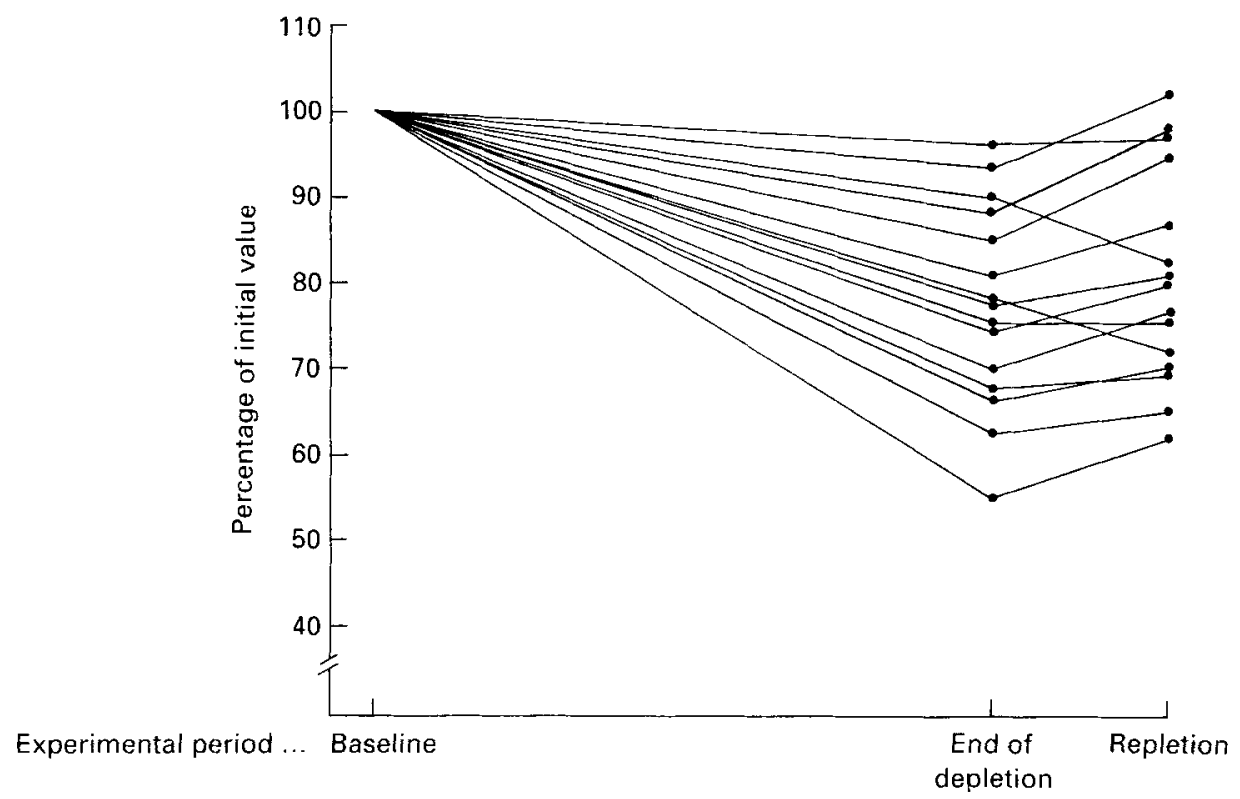

Fig. 1. Changes in total alkaline phosphatase (EC 3.1.3.1) activity in erythrocyte membranes (expressed as percentage of the initial value) during experimental zinc depletion and repletion in young adult male subjects. For details of procedures, see pp. $516 \cdot 519$.

- end of depletion) of AP-EM expressed as a percent of the initial value. The decrease in AP-EM was consistent in all fifteen subjects, averaging $23 \%$, and ranging from 3.7 to $44.9 \%$. The total decrease in AP-EM correlated significantly with the activity of this enzyme at baseline $(r 0.64 ; P=0.01)$, and negatively with initial urinary $\mathrm{Zn}$ concentration $(r-0.68 ; P<0.05)$. No significant associations were observed when the total change of AP-EM was correlated with: total change in plasma $\mathrm{Zn}$, total change in urinary $\mathrm{Zn}$, total 
change in erythrocyte membrane $\mathrm{Zn}$, initial plasma $\mathrm{Zn}$, initial erythrocyte membrane $\mathrm{Zn}$ and initial total erythrocyte $\mathrm{Zn}$ concentration. The addition of $\mathrm{Zn}$ in vitro (5-100 $\mu \mathrm{M}$ final concentration in the cuvette) did not significantly affect the activity of AP-EM.

\section{DIS CUSSION}

\section{Indices of Zn status in neutrophils}

The conventional approach when using mixed leukocytes, or specific sub-populations of leukocytes, to assess $\mathrm{Zn}$ status has been to determine the concentration of $\mathrm{Zn}$ in these cells (Prasad \& Cossack, 1982; Milne et al. 1985a,b; Prasad, 1985a,b). This approach, however, has produced equivocal results.

There are important technical considerations regarding the separation of blood cells for mineral analysis. Mean $\mathrm{Zn}$ concentrations in neutrophils and lymphocytes (separated simultaneously using Histopaque-Ficoll-hypaque gradients) in studies conducted in 1980-83 were between 104 and $116 \mu \mathrm{g} / 10^{10}$ cells (Prasad \& Cossack, 1982; Whitehouse et al. 1982; Ballester \& Prasad 1983), whereas results provided by the same laboratory 5-8 years later were about 50\% lower for both cellular types (Pai \& Prasad, 1988). This discrepancy is partly the result of the observations by Milne et al. (1985a), who (using Percoll gradients) reported that the separation procedure used earlier had yielded lymphocyte preparations contaminated with platelets which artificially increased the $\mathrm{Zn}$ content. The effect of the separation procedure on the neutrophil fraction is less clear. In a density-gradient system typically used to separate platelets, lymphocytes and neutrophils, cells become separated in this same sequence from the top to the bottom of the test-tube (Milne et al. 1985a). As a result, the risk of contamination with platelets is high for the lymphocyte fraction but low for neutrophils, making it difficult to understand the claim by some investigators (Pai \& Prasad, 1988) that improved isolation procedures were responsible for the reductions in the 'normal values' for both lymphocytes and neutrophils. In our study, we initially attempted to separate the cellular types using Percoll gradients, but we observed that this reagent contained $\mathrm{Zn}$ as a contaminant $(0.32 \mu \mathrm{g} / \mathrm{ml})$. Consequently, we used a Ficoll-Hypaque gradient, but did not attempt to isolate the lymphocyte fraction to avoid contaminating the other cell types with plateletş.

The effects of $\mathrm{Zn}$ status on concentrations of $\mathrm{Zn}$ in neutrophils are equivocal (Prasad et al. 1978; Prasad \& Cossack, 1982; Ballester \& Prasad, 1983; Milne et al. 1987; Rabbani et al. 1987). The formation of neutrophils from their earliest stages of development until their release into the bloodstream takes approximately $8-9 \mathrm{~d}$. Their half-life in the circulation pool is about $7 \mathrm{~h}$ (Simmons, 1989). Cells are removed from this pool randomly rather than according to their age as is the case of erythrocytes and platelets (Wintrobe et al. 1981). Consequently, if it is assumed that neutrophils are sensitive to alterations in $\mathrm{Zn}$ status, a short period of 2-4 weeks should, theoretically, be sufficient to detect changes in neutrophil variables. Such changes in neutrophil $\mathrm{Zn}$ were not observed during the 7-week $\mathrm{Zn}$-depletion period of the present study, despite the development of mild $\mathrm{Zn}$ deficiency, as indicated by the changes observed in plasma, urinary and hair $\mathrm{Zn}$ concentrations, immune function and taste acuity (Ruz ef al. 1991).

As neutrophil $\mathrm{Zn}$ concentrations were analysed on a weekly basis in the present study, changes in their responses to the experimental diets could be monitored very carefully. For example, when all the eleven weekly measurements were included in the ANOVA of repeated measures, no significant differences were apparent. In contrast, if only the baseline and the end of depletion points were compared by using a paired $t$ test, the resulting $P$ value was $0 \cdot 04$. Such a simplistic approach fails to recognize some inconsistencies during the 
study; for instance, the lowest mean value observed (seventh week of depletion) was preceded by a value closer to that at the baseline rather than that obtained at the end of depletion.

In the present study we also assessed the response of two $\mathrm{Zn}$ metallo-enzymes in neutrophils ( $\alpha$-D-mannosidase and alkaline phosphatase) as potential indices of $\mathrm{Zn}$ status in humans. To our knowledge, this is the first study to assess the response of $\alpha$-Dmannosidase in neutrophils during experimentally induced $\mathrm{Zn}$ depletion-repletion in humans. Several species of $\alpha$-mannosidase exist in mammalian tissues and fluids, and are classified according to their optimum pH (Snaith, 1977). Only acid $\alpha$-mannosidase is said to be $\mathrm{Zn}$-dependent (Snaith, 1977). It is located in the lysosomal fraction and has an optimum $\mathrm{pH}$ in the range of 4.0-4.6. Our findings (Table 1) indicate that the activity of this enzyme in neutrophils (and plasma) is not a useful index of $\mathrm{Zn}$ status. In addition, no significant changes were observed in the activity of neutrophil alkaline phosphatase in our study. Some (Shrader \& Hurley, 1972; Baer et al. 1985), but not all (Prasad \& Cossack, 1984; Schiliro et al. 1987) investigators have also failed to show that the activity of alkaline phosphatase in neutrophils or leukocytes, or both, is a valid index of $\mathrm{Zn}$ status.

\section{Indices of $\mathrm{Zn}$ status in platelets}

The use of platelets as a biopsy tissue for the assessment of $\mathrm{Zn}$ status has been advocated by some investigators (Pai \& Prasad, 1988). Others, however, have failed to document any significant changes in platelet $\mathrm{Zn}$ concentrations during experimental $\mathrm{Zn}$ depletion in human (Milne et al. 1987) or animal (Gordon \& O'Dell, 1980; Milne et al. 1985 b) studies. Our results support these latter observations and emphasize the insensitivity of platelet $\mathrm{Zn}$ concentrations to changes in $\mathrm{Zn}$ status. Values for platelet $\mathrm{Zn}$ concentrations reported here (Table 2) are within the range for healthy adults $\left(29 \cdot 5-73 \cdot 3 \mathrm{nmol} \mathrm{Zn} / 10^{10}\right.$ cells (Milne et al. 1985a, 1987; Pai \& Prasad, 1988).

Some functional defects in platelets have been described in $\mathrm{Zn}$-deficient animals (Gordon \& O'Dell, 1980) and humans (Gordon et al. 1982), some of which (i.e. impaired platelet aggregation) have been related to a reduction in MPV (Ralston \& Milne, 1988). In our study, MPV in whole blood did not show any significant change in response to a 7-week period of $\mathrm{Zn}$ depletion. No explanation can be given at present for the significant correlations observed at baseline between MPV and neutrophil $\alpha$-D-mannosidase, and between neutrophil $\mathrm{Zn}$ and total circulating leukocyte count. More research is necessary to elucidate the nature and significance (if any) of these associations.

\section{Indices of $Z n$ status in erythrocytes}

Erythrocyte $\mathrm{Zn}$ concentrations do not reflect short-term changes in $\mathrm{Zn}$ status; evidence for their use as a valid index of $\mathrm{Zn}$ status in medium- to long-term studies of controlled $\mathrm{Zn}$ deficiency (i.e. 6 or more weeks) is controversial. Earlier observations indicated some degree of sensitivity of erythrocyte $\mathrm{Zn}$ to fluctuations in $\mathrm{Zn}$ status (Buerk et al. 1973). More recent reports of human studies, based on results obtained after feeding low-Zn diets for periods ranging from 4 to 28 weeks (Prasad et al. 1978; Baer \& King, 1984; Milne et al. 1987; Rabbani et al. 1987), indicate that erythrocyte $\mathrm{Zn}$ is unchanged during controlled $\mathrm{Zn}$ depletion. This finding is consistent with that noted in animals with severe $\mathrm{Zn}$ deficiency (Milne et al. 1985b). Consequently, the lack of response of erythrocyte $\mathrm{Zn}$ concentration as an index of $\mathrm{Zn}$ status reported here is not unexpected. In the present study, inter-subject variation in initial erythrocyte $\mathrm{Zn}$ concentrations was high but intra-subject variation was low.

The erythrocyte membrane was also investigated as a potential tissue for the assessment of $\mathrm{Zn}$ status in the present study, utilizing both a static (i.e. $\mathrm{Zn}$ concentration) and a 
functional (i.e alkaline phosphatase) index of $\mathrm{Zn}$ status. The response of erythrocyte membrane $\mathrm{Zn}$ concentration to $\mathrm{Zn}$ deficiency has been investigated in rats (Bettger \& Taylor, 1986; Johanning et al. 1989) and pigs (Johanning et al. 1989), but not in humans. In our study, erythrocyte membrane $\mathrm{Zn}$ concentrations were slightly higher than levels reported by McWilliams et al. (1983) in patients with taste and smell dysfunction. Moreover, although erythrocyte membrane $\mathrm{Zn}$ concentrations tended (not significantly) to decrease with time $(P=0.06)$, the fall was only $6 \%$ after 7 weeks of the low-Zn diets, whereas at the end of the follow-up phase, erythrocyte membrane $\mathrm{Zn}$ concentrations had fallen by $20 \%$. This slow response in erythrocyte membrane $\mathrm{Zn}$ concentration limits the use of erythrocyte membrane $\mathrm{Zn}$ concentration as an index of $\mathrm{Zn}$ status.

The activity of several membrane-bound enzymes is apparently affected by $\mathrm{Zn}$ deficiency in a variety of tissues, although information on the erythrocyte membrane is limited. For instance, the activity of $5^{\prime}$-nucleotidase (EC 3.1.3.5), an enzyme suggested to be a $\mathrm{Zn}$ metallo-enzyme (Johanning et al. 1988), is significantly reduced in erythrocyte membranes in pigs and rats consuming low-Zn diets (Johanning et al. 1988). Important differences in the activity of 5 -nucleotidase in erythrocyte membranes among species exist, for instance, the activity of this enzyme in erythrocyte membranes from $\mathrm{Zn}$-adequate pigs can be up to thirty times higher than that in erythrocyte membranes from normal rats (Johanning et al. 1988). Furthermore, the activity of $\mathrm{Ca}, \mathrm{Mg}$-ATPase in erythrocyte membranes was reduced in pigs consuming low- $\mathrm{Zn}$ diets, but not in $\mathrm{Zn}$-deficient rats (Johanning et al. 1988). In our study, 5'-nucleotidase activity was not detected in erythrocyte membranes, an observation consistent with that of Delaunay et al. (1978).

In the present study we also developed a functional test to evaluate $\mathrm{Zn}$ status based on the simultaneous determination of the total alkaline phosphatase and neutral phosphatase activities in erythrocyte membranes. The activity of alkaline (Galdes \& Hill, 1979), but not neutral phosphatase (W. J. Bettger, personal communication) is a $\mathrm{Zn}$-dependent function. Therefore, different patterns should be observed during experimental $\mathrm{Zn}$ deficiency if $\mathrm{Zn}$ status is truly reflected by the Zn-dependent portion of the phosphatase activity. In our study, AP-EM, but not the plasma AP activity (Ruz et al. 1991), showed a consistent decrease during the Zn-depletion phase; neutral phosphatase activity was unaffected. Furthermore, the change in AP-EM activity was significant after only 4 weeks of low-Zn diets, and the magnitude of change was positively correlated with baseline activity. These findings suggest that AP-EM may have potential as an index for diagnosing mild deficiency in humans. During the $\mathrm{Zn}$-repletion phase, AP-EM was not significantly increased, probably because a 2 -week period was not sufficient to restore the activity. Nevertheless, it is noteworthy that eleven of the fifteen subjects had increased AP-EM during the 2 weeks of the Zn-repletion phase (Fig. 1).

The reasons for the results for the activity of AP-EM at week 16 (follow-up) are unclear. During this period the subjects were consuming their own self-selected diets. Furthermore, the mechanisms involved in the observed changes in total AP-EM during the $\mathrm{Zn}$-depletion and $\mathrm{Zn}$-repletion periods remain to be investigated. The enzyme responsible for these changes must be purified to confirm that it is truly a $\mathrm{Zn}$ metallo-enzyme. It we make this assumption, two possible mechanisms may explain the changes observed. In the first, alkaline phosphatase may lose $\mathrm{Zn}$ to counteract the decrease in plasma $\mathrm{Zn}$, followed by degradation of the apo-enzyme by proteinases. Consequently, a return to the original activity must await de novo synthesis. The second possibility is that $\mathrm{Zn}$ deficiency decreases the amount of the holo-enzyme anchored to the membrane. If the enzyme is an endoenzyme, it would move to the cytosol where it remains or is degraded; if the enzyme is an ecto-enzyme, then it would be released into the plasma. In both cases, a return of the activity to the original levels must await de novo synthesis. 
In summary, we have documented significant changes in AP-EM during an experimentally-controlled $\mathrm{Zn}$-depletion study. Comparable changes were not observed for the activity of erythrocyte membrane neutral phosphatase and for alkaline phosphatase and $\alpha$ $D$-mannosidase activities in neutrophils. The mechanisms underlying the observed changes in AP-EM, however, warrant further investigation before confirming its use as a functional index of $\mathrm{Zn}$ status in humans. In the present study we have also monitored the concentrations of $\mathrm{Zn}$ in neutrophils, platelets, erythrocytes, and erythrocyte membranes during experimentally-controlled $\mathrm{Zn}$ depletion and repletion. Results show that none of these indices detected the alterations in $\mathrm{Zn}$ status indicated by changes in plasma, urine, hair $\mathrm{Zn}$ concentrations, taste acuity and cellular immune response. Hence, they are not sensitive indices of $\mathrm{Zn}$ status. Similarly, the concentration of $\mathrm{Zn}$ in erythrocyte membranes is not sensitive to short-term changes in $\mathrm{Zn}$ status; its usefulness as an index of long-term Zn status remains to be determined.

This work was supported by the National Sciences and Engineering Research Council of Canada and Canada Packers Inc., Toronto, Ontario M6N 1 K4.

\section{REFERENCES}

Ваer, M. T. \& King, J. C. (1984). Tissue zinc levels and zinc excretion during experimental zinc depletion in young men. American Journal of Clinical Nutrition 39, 556-570.

Baer, M. T., King, J. C., Tamura, T., Margen, S., Bradfield, R. B., Weston, W. L. \& Daugherty, N. A. (1985). Nitrogen utilization, enzyme activity, glucose intolerance and leukocyte chemotaxis in human experimental zinc depletion. American Journal of Clinical Nutrition 41, 1220-1235.

Ballester, O. F. \& Prasad, A. S. (1983). Anergy, zinc deficiency, and decreased nucleoside phosphorylase activity in patients with sickle cell anemia. Annals of Internal Medicine 98, 180-182.

Bettger, W. J. \& Taylor, C. G. (1986). Effects of copper and zinc status of rats on the concentration of copper and zinc in the erythrocyte membrane. Nutrition Research 6, 451-457.

Buerk, C. A., Chandy, G., Pearson, E., MacAuly, M. S. \& Soroff, H. S. (1973). Zinc deficiency: effect on healing and metabolism in man. Surgical Forum 24, 101 - I03.

Clegg, M. S., Keen, C. L., Lonnerdal, B. \& Hurley, L. (1988). Influence of ashing techiques on the analysis of trace elements in animal tissue. I. Wet ashing. Biological Trace Element Research 3, 105-107.

De Chatelet, L. R. \& Cooper, M. R. (1970). A modified procedure for the determination of leukocyte alkaline phosphatase. Biochemical Medicine 4, 62-68.

Delaunay, J., Fischer, S., Torolero, M., Piau, J. P. \& Schapira, G. (1978). Absence of any detectable activity of the membrane marker enzyme 5'-nucleotidase in human red blood cells. Biomedical Express 29, 173-175.

Faber, C. N. \& Glew, R. H. (1983). $\alpha$-D-Mannosidase. In Methods of Enzymatic Analysis, 3rd ed., vol. 14, pp. 230240 [H. U. Bergmeyer, editor]. Weinheim: Verlag Chemie.

Galdes, A. \& Hill, H. A. O. (1979). Metalloenzymes. In Inorganic Biochemistry, vol. 1, pp. 317335 [H. A. O. Hill, editor]. London: The Chemical Society.

Gordon, P. R. \& O'Dell, B. L. (1980). Rat platelet aggregation impaired by short-term zinc deficiency. Journal of Nutrition $110,2125-2129$.

Gordon, P. R., Woodruff, C. W., Anderson, H. L. \& O’Dell, B. L. (1982). Effect of acute zinc deprivation on plasma zinc and platelet aggregation in adult males. American Journal of Clinical Nutrition 35, 113-119.

Health and Welfare (1990). The Repont of the Scientific Review Committee, Nutrition Recommendations. Minister of Supply and Services Canada. Ottawa: Health and Welfare Canada.

Johanning, G. L. \& O'Dell, B. L. (1988). Effect of zinc deficiency on erythrocyte (RBC) plasma enzyme activities. FASEB Journal 2, A636.

Johanning, G. L. \& O'Dell. B. L. (1989). Effect of zinc deficiency and food restriction in rats on erythrocyte membrane zinc, phospholipid and protein content. Journal of Nutrition 119, 1654-1660.

Johanning, G. L., Bobilya, D. J., Browning, J. D. \& O'Dell, B. L. (1989) Effect of zinc status on protein, zinc and phospholipid composition of pig red cell (RBC) membranes. FASEB Journal 3, A457 Abstr.

Johanning, G. L., Miller, D. S. \& O'Dell, B. L. (1988). Effect of zinc deficiency on lipid and protein profiles of the erythrocyte membrane. In Trace Elements in Man and Animals 6, pp. 363.364 [L. S. Hurley, C. L. Keen, B. Lonnerdal and R. B. Rucker, editors]. New York: Plenum Press.

McWilliams, P. L.. Agarwal, R. P. \& Henkin, R. I. (1983). Zinc concentration in erythocyte membranes in normal volunteers and in patients with taste and smell dysfunction. Biological Trace Element Research $5,1 \ldots 8$.

Markwell, M. A., Hass, S. M., Bieber, L. L. \& Tolbert, N. E. (1978). A modification of the Lowry procedure to simplify protein determination in membrane and lipoprotein samples. Analytical Biochemistry 87, 206-210. 
Meadows. N. I., Ruse, W., Smith, M. F., Day, J., Keeling, P. W. N., Scopes, I. W., Thompson, R. P. H. \& Bloxam, D. L. (1981). Zinc and small babies. Lancet ii 11351137.

Milne, D. B., Canfield, W. K., Gallagher, S. K., Hunt, J. R. \& Klevay, L. M. (1987). Ethanol metabolism in postmenopausal women fed a diet marginal in zinc. American Journal of Clinical Nutrition 46, 688-693.

Milne, D. B., Ralston, N. V. C. \& Wallwork, J. C. (1985a). Zinc content of cellular components of blood: methods for cell separation and analysis evaluated. Clinical Chemistry 31, 65-69.

Milne, D. B., Ralston, N. V. C. \& Wallwork, J. C. (1985b). Zine content of blood cellular components and lymph node and spleen lymphocytes in severely zinc-deficient rats. Journal of Nutrition 115, 1073-1078.

Nishi, Y. (1980). Zinc levels in plasma, erythrocytes, and leukocytes in healthy children and adults. Hiroshima Journal of Medical Sciences 29, 7-13.

Pai, L. H. \& Prasad, A. S. (1988). Cellular zinc in patients with diabetes mellitus. Nutrition Research $\mathbf{8 , 8 8 9 - 8 9 7 .}$

Prasad, A. S. (1985a). Clinical manifestations of zinc deficiency. Annual Review' of Nutrition 5, 341-363.

Prasad, A. S. (1985b). Laboratory diagnosis of zine deficiency. Journal of the American College of Nutrition 4 , 591-598.

Prasad, A. S. \& Cossack, Z. T. (1982). Neutrophil zinc: an indicator of zinc status in man. Transactions of the Association of Americun Physicians 95, 165-176.

Prasad, A. S. \& Cossack, Z. T. (1984). Zinc supplementation and growth in sickle cell disease. Annals of Internal Medicine 100, 367-371.

Prasad, A. S., Rabbani, P., Abbasi, A., Bowersox, E. \& Fox, M. R. S. (1978). Experimental zine deficiency in humans. Annals of Internal Medicine 89, 483-490.

Rabbani, P. I., Prasad, A. S., Tsai, R., Harland, B. F. \& Spivey Fox, M. R. (1987). Dietary model for production of experimental zinc deficiency in man. American Journal of Clinical Nutrition 45, 1514-1525.

Ralston, N. V.C. \& Milne, D. B. (1988). Reduced platelet size in zinc deficiency: implications in assays of conditions associated with zinc deficiency. FASEB Journal 2, A867 Abstr.

Ruz, M., Cavan, K. R., Bettger, W. J., Thompson, L. U., Berry, M. \& Gibson, R. S. (1991). Development of a dietary model for the study of marginal zinc deficiency in humans. Evaluation of some biochemical and functional indices of zinc status. American Journal of Clinical Nutrition 53, 1-9.

Schiliro, G., Russo, A., Azzia, N., Russo Mancusso, G., Di Gregorio, F., Romeo, M. A., Fallico, R. \& Sciacca, S. (1987). Leukocyte alkaline phosphatase (LAP). A useful marker of zinc status in $\beta$-thalassemic patients. American Journal of Pediatric Hematology Oncology 9, 149-152.

Shrader, R. E. \& Hurley, L. S. (1972). Enzyme histochemistry of peripheral blood and bone marrow in zincdeficient rats. Journal of Laboratory Investigation. 20, 566-571.

Simmons, A. (1989). Hematology. A Combined Theoretical and Technical Approach. Philadelphia: W. B. Saunders.

Snaith, S. M. (1977). Mutiple $\alpha$-mannosidase activities in mammalian tissues are shown by metal-ion activation. Biochemical Journal 163,557 564 .

Snedecor, G. W. \& Cochran, W. G. (1980). Stastical Methods, 7th ed. Ames, IA: The Iowa State University Press.

Solomons, N. W. (1979). On the assessment of zine and copper nutriture in man. American Joumal of Cinical Nutrition 32, 856871 .

SPSS, Inc. (1986). SPSSx User's Guide, 2nd ed. New York, NY: McGraw-Hill Book Co.

Steck, T. L., Weinstein, R. S., Straus, J. H. \& Wallach, D. F. H. (1970). Inside-out red cell membrane vesicles: preparation and purification. Science 168, 255-257.

Whitehouse, R. C., Prasad, A. S., Rabbani, P. I. \& Cossack, Z. T. (1982). Zinc in plasma, neutrophils, lymphocytes, and erythrocytes as determined by flameless atomic absorption spectrophotometry. Clinical Chemistry 28, 475-480.

Wintrobe, M. M., Lee, G. R., Boggs, D. R., Bithell, T. C., Foerster, J. Athens, J. W. \& Lukens, J. N. (editors) (1981). Clinical Hematology, 8th ed. Philadelphia: Lea and Febiger. 